\title{
Benthic algae as major precursors of oil-prone kerogen - A case study from the Hungarian Middle Miocene
}

\author{
István Vető ${ }^{1 *}$, Katalin Báldi ${ }^{2}$, Stjepan Ćorić ${ }^{3}$, Magdolna Hetényi ${ }^{4}$, \\ Attila Demény ${ }^{5}$, István Futó ${ }^{6}$ \\ ${ }^{1}$ Consultant Geochemist, Budapest, Hungary \\ ${ }^{2}$ Department of Physical and Applied Geology, Eötvös Loránd University, Budapest, Hungary \\ ${ }^{3}$ Geological Survey of Austria, Vienna, Austria \\ ${ }^{4}$ Department of Mineralogy and Geochemistry, University of Szeged, Szeged, Hungary \\ ${ }^{5}$ Institute for Geological and Geochemical Research, Research Centre for Astronomy and Earth Science, \\ Hungarian Academy of Sciences, Budapest, Hungary \\ ${ }^{6}$ MTA Institute for Nuclear Research, Debrecen, Hungary
}

Received: February 21, 2016; accepted: September 6, 2016

This study is intended to clarify the depositional environment of a 180-m-thick, immature, limy Middle Miocene oil source rock interval, cored in the Zala Basin, western Hungary. For this purpose, a highly interdisciplinary approach was applied combining simple, standard micropaleontological, isotopic, and organic geochemical methods, rarely applied together. Foraminifera were studied for estimating bottom oxygenation and water depth, while nannoplankton biostratigraphy permitted for estimating the rate of sedimentation. The studied source rocks were deposited in a rather shallow sea, below well-oxygenated bottom water. The abundant epiphytic foraminiferal fauna proves that the bottom was densely inhabited by benthic algae, while the high $\delta^{13} \mathrm{C}_{\text {org }}(>-22 \%$ ) clearly indicates massive benthic algal contribution to the kerogen. Mass accumulation rate of the limy upper part of the NN5 nannoplankton biozone, the oil source interval included, was very high $\left(551 \mathrm{t} / \mathrm{m}^{2} / \mathrm{Ma}\right)$. In spite of moderate productivity and good oxygenation of the bottom, rapid accumulation of carbonate, produced partly by benthic algae, assured both the great relative weight of the marine organic components and their good preservation. Our results provide the first proof for the possibility of a major contribution of benthic algae to oil-prone kerogen.

Keywords: benthic algae, epiphytic foraminifera, nannoplankton, ${ }^{13} \mathrm{C}_{\text {org }}$, oil-prone

*Corresponding author: István Vetô; Balogh Ádám utca 18/C, H-1026 Budapest, Hungary

E-mail: vetoie3840@gmail.com

This is an open-access article distributed under the terms of the Creative Commons Attribution License, which permits unrestricted use, distribution, and reproduction in any medium for non-commercial purposes, provided the original author and source are credited. 


\section{Introduction}

The Neogene Pannonian Basin System (PBS), surrounded by the Carpathian, Dinarides, and Alps (Fig. 1), is a classical petroleum province. Apart from the Jurassicsourced oil and gas in the Vienna Basin (Ladwein 1988) and the Triassic-sourced oil in the Zala Basin (Koncz 1990; Clayton and Koncz 1994), the bulk of the petroleum accumulated in the PBS is considered to be the product of marly, limy Miocene sediments, widely developed in the basin system.

The Miocene-sourced oils of Hungary form two distinctly different groups: while oils discovered in SE Hungary have been sourced from Late Middle Miocene and Late Miocene brackish and lake sediments, those discovered in the Zala and Drava Basins (SW Hungary) have been generated mostly in the Middle Miocene marine sediments (e.g., Koncz 1990; Šarković et al. 1992; Clayton and Koncz 1994; Clayton et al. 1994; Barić et al. 2000; Hasenhüttl et al. 2001; Lučić et al. 2001; Troskot-Corbić et al. 2009; Badics et al. 2011; Király et al. 2011). On the other hand, according to the available data (Koncz 1990; Clayton and Koncz 1994; Clayton et al. 1994; Fekete et al. 2010), the $\delta^{13} \mathrm{C}$ of oils accumulated in SE Hungary is more negative than that of the Miocenesourced Zala Basin oils.

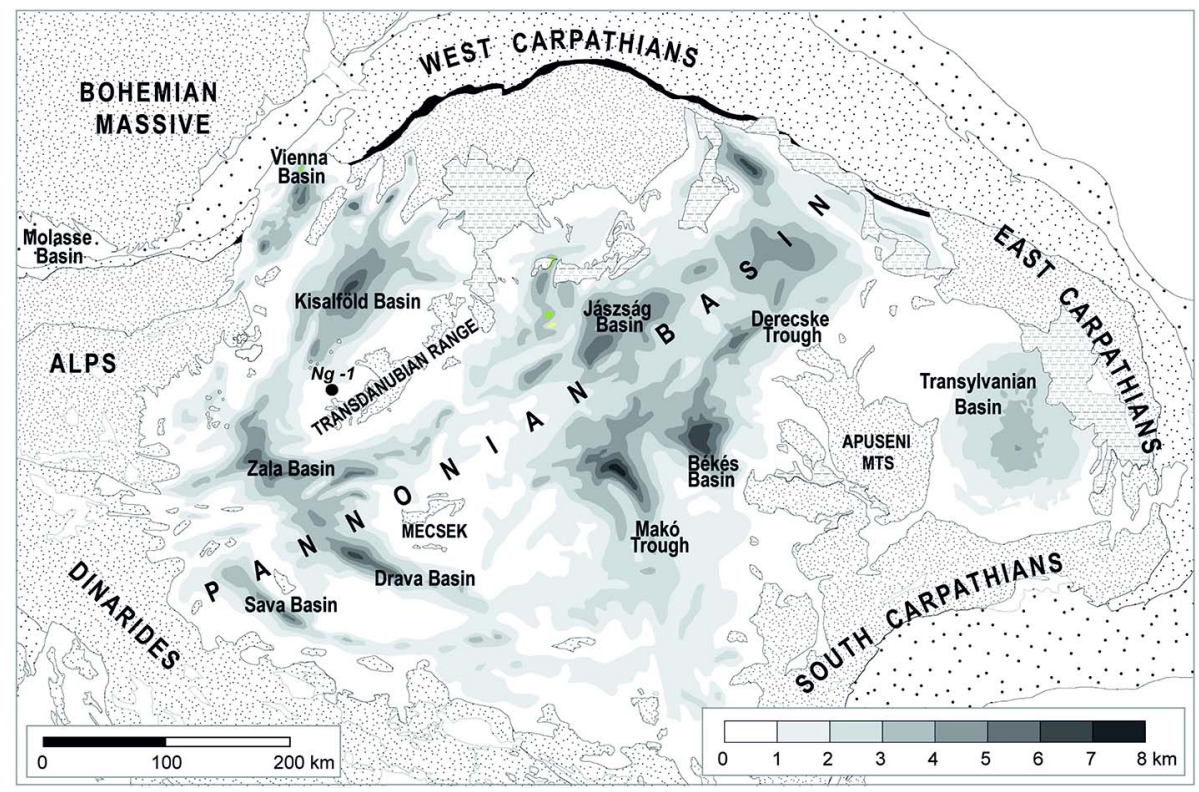

Fig. 1

Iso-thickness map of the Pannonian Basin System with location of the $\mathrm{Ng} 1$ well (after Horváth and Royden 1981) 
Many case studies deal with the hydrocarbon potential $\left(\mathrm{HC}_{\mathrm{pot}}\right)$ of the Miocene source sediments in different parts of the PBS (e.g., Alajbeg et al. 1990, 1996; Šarković et al. 1992; Clayton and Koncz 1994; Clayton et al. 1994; Pap and Pap 1997; Barić et al. 1998; Badics et al. 2011), but sedimentological, paleontological, or even lithological information about them are rather parsimoniously provided.

Unfortunately, the few papers focusing on their depositional environment are mostly free of source rock considerations (e.g., Pavelić et al. 1998; Magyar et al. 2004). The only exception is the work of Malvić and Majstorović-Busić (2012), dealing with Upper Badenian-Pannonian source rocks of the Bjelovar Depression, Sava Basin, Croatia. Due to the restricted scope of applied methods in previous work in studying the depositional environment of the PBS source rocks, it is still poorly understood.

An additional difficulty for deciphering the relationship between source rock quality and depositional environment derives from the fact that some of the case studies referred to above deal with mature or marginally mature sediments, from which a part of the generated hydrocarbons have been already expulsed, meaning that their $\mathrm{HC}_{\text {pot }}$ decreased during late burial.

Preliminary studies (Vetö et al. 2010; Badics and Vetö 2012) revealed that the Nagygörbö 1 ( $\mathrm{Ng} \mathrm{1)} \mathrm{scientific} \mathrm{well,} \mathrm{cored} \mathrm{at} \mathrm{the} \mathrm{northeastern} \mathrm{margin} \mathrm{of} \mathrm{the} \mathrm{Zala} \mathrm{Basin}$ (for location see Fig. 1), penetrated Middle Miocene (Badenian age) fair to good quality but immature source rocks of limy marl/limestone lithology in more than $100 \mathrm{~m}$ thickness. In spite of its marginal position in the basin, this fully cored Badenian section offers a unique possibility to understand the relationship between depositional environment and source rock quality.

In this study, our results are obtained by a combined application of standard geochemical and micropaleontological methods on the marine Middle Miocene (Badenian age) sediments cored between 400 and $700 \mathrm{~m}$ depth by the $\mathrm{Ng} 1$ well. The biostratigraphy and the trophic status of the sea are based on the calcareous nannoplankton record, while recognizing water depth and the oxygenation of the bottom water is based on foraminifera. Organic carbon isotopic composition $\left(\delta^{13} \mathrm{C}_{\text {org }}\right)$ and Rock-Eval indices are used as proxies to estimate the relative contribution of planktonic, benthic, and land plant components to kerogen.

\section{Geologic setting}

This section is based on the Open File Report No. 1775/1 of the Hungarian Office for Mining and Geology (HOMG) dealing with the $\mathrm{Ng} 1$ well, cored in 1972 to a depth of $1,517 \mathrm{~m}$.

Oligocene sediments are discordantly covered by Miocene ones at 1,067 m depth. The bottom part of the Miocene, penetrated between 1,067 and $923 \mathrm{~m}$, is built up by clay, marl, and gravel, mostly of terrestrial facies.

The bulk of the Miocene, developed between 923 and $350.7 \mathrm{~m}$, consists of finegrained, non- or slightly layered marine marl and limestone with traces of bioturbation 


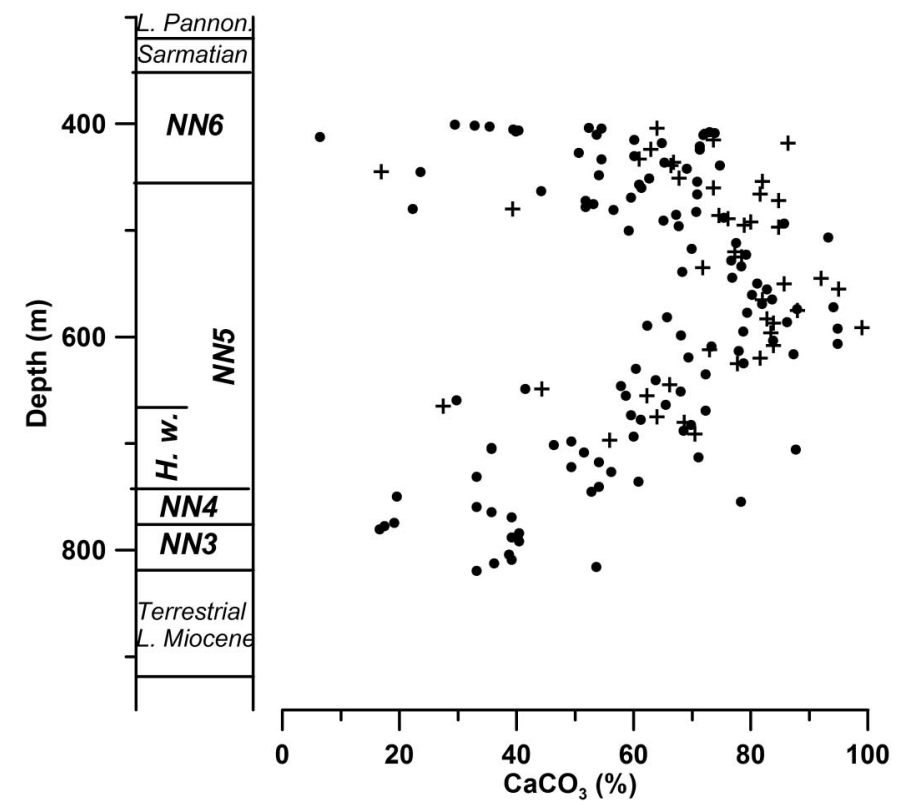

Fig. 2

Variation of the carbonate content with depth in the 350-850 m interval, $\mathrm{Ng} 1$ corehole. The data points are from Open File Report No. 1775/1, HOMG

in some parts. Carbonate content (Fig. 2) gradually increases upward from $20-30 \%$ to $80-95 \%$ between 800 and $550 \mathrm{~m}$, then decreases with a high scatter to $30-70 \%$ between 550 and $400 \mathrm{~m}$. Several red alga-rich limestone beds of $0.1-1 \mathrm{~m}$ thickness were penetrated between 706 and $410.4 \mathrm{~m}$. Above $407.5 \mathrm{~m}$, several sand layers were penetrated, while the uppermost $40 \mathrm{~m}$ of the marine Middle Miocene consists of sand. The discordantly overlying uppermost Middle Miocene (Sarmatian) and Late Miocene (Lower Pannonian) strata are built up mainly of clastic sediments of brackish and lacustrine origin.

\section{Samples and techniques}

Altogether, 28 samples were taken from 762.9 to $404 \mathrm{~m}$ for studying the calcareous nannoplankton with the aim of refining the stratigraphy and tracing paleoecological changes. The 44 samples taken from 697 to $404 \mathrm{~m}$ were split into subsamples to study foraminiferal assemblages and Rock-Eval indices or determine carbonate content. Organic and inorganic carbon isotope measurements were carried out on about the half of this sample set. 


\section{Preparation and determination of calcareous nannoplankton}

Smear slides were analyzed using a light microscope $(1,000 \times$ magnification $)$ at normal and crossed nicols. To trace paleoecological changes, at least 300 specimens from each sample were counted. For biostratigraphic interpretation, the standard nannoplankton zonation of Martini (1971) was used.

\section{Preparation and determination of foraminifera}

Samples were soaked in hydrogen peroxide solution for several weeks. In spite of this aggressive treatment, samples taken from below $612 \mathrm{~m}$ did not disintegrate. Hence, only the upper two-thirds of the 697-404 m interval were studied for foraminifera.

The $125 \mu \mathrm{m}-0.6 \mathrm{~mm}$ fraction was picked for benthic foraminifera and mounted on slides from the split reaching the statistically required minimum of 200 specimens. Altogether, only 14 samples taken between 612 and $404 \mathrm{~m}$ were eligible for further statistics by satisfying this requirement. Determining foraminifera to the species level was difficult due to foraminiferal tests frequently covered by calcareous lining hiding characteristic features of the test. This resulted in the high number of undetermined calcareous specimens.

As will be discussed in more detail further on, the far from ideal preservation of foraminifera resulted in some limitations for the utility of multi-proxy approach to reconstruct depositional environment.

\section{Chemical and isotope measurements}

About 20-30 g of core sample was ground in a Fritsch ball mill.

Rock-Eval indices - Hydrogen Index (HI), characterizing the hydrogen richness of kerogen, and the temperature of the maximal intensity of the pyrolitic hydrocarbon liberation $\left(T_{\max }\right)$, characterizing the maturity of the kerogen - together with the total organic carbon (TOC) content were determined on a Delsi Oil Show Analyser under standard conditions at the Department of Mineralogy, Geochemistry and Petrography in the University of Szeged.

Amounts of inorganic constituents were weighed in the laboratory of the Geological Institute of Hungary. Major element contents were measured with the inductively coupled plasma atomic emission spectroscopy technique after fusion with Li metaborate. The inorganic carbon content was measured volumetrically after $\mathrm{HCl}$ treatment. Uncertainties of the measurements were 10-20 relative percentages, respectively.

Organic carbon content of a set of decarbonated samples was oxidized at $480{ }^{\circ} \mathrm{C}$ in a Pyrex tube under vacuum following the method of Sofer (1980). The carbonate content of the same sample set was digested using the conventional $\mathrm{H}_{3} \mathrm{PO}_{4}$ method (McCrea 1950). In both cases, isotope ratios of the $\mathrm{CO}_{2}$ generated were measured with a Finnigan MAT Delta $\mathrm{S}$ mass spectrometer at the Institute for Geological and 
Geochemical Research in Budapest. The reproducibility of the $\delta^{13} \mathrm{C}$ data is better than $0.2 \%$.

Organic carbon content of another set of decarbonated samples mixed with $\mathrm{CuO}$ was oxidized at $850{ }^{\circ} \mathrm{C}$. The carbonate content of the same sample set was digested using the conventional $\mathrm{H}_{3} \mathrm{PO}_{4}$ method (McCrea 1950). In both cases, isotope ratios of the $\mathrm{CO}_{2}$ generated were measured with a Thermo Finnigan Delta plus XP mass spectrometer at the Institute of Nuclear Research in Debrecen. The reproducibility of the $\delta^{13} \mathrm{C}$ data is better than $0.15 \%$.

\section{Results}

\section{Biostratigraphy}

The observed calcareous nannoplankton species are listed in Supplementary Material A.

Based on calcareous nannoplankton, the $\mathrm{Ng} 1$ Middle Miocene sequence can be subdivided into three nannoplankton zones: NN4, NN5, and NN6.

The last occurrence (LO) of Sphenolithus heteromorphus, which defines the NN5/ NN6 boundary, was observed between samples 436 and $472 \mathrm{~m}$. This biostratigraphically important species has its last appearance datum (LAD) at $13.53 \mathrm{my}$ (Lourens et al. 2004), which fits well with the data of Abdul Aziz et al. (2008). The accompanying assemblages in the Discoaster exilis Zone (nannoplankton Zone NN6) are characterized by high percentages of reticulofenestrids: Reticulofenestra gelida, Reticulofenestra haqii, Reticulofenestra minuta, and Reticulofenestra pseudoumbilica. The species Coccolithus pelagicus, Coronosphaera mediterranea, Cyclicargolithus floridanus, Geminilithella rotula, Helicosphaera carteri, Helicosphaera walbersdorfensis, and Umbilicosphaera jafari occur regularly.

The absence of Helicosphaera ampliaperta and the presence of S. heteromorphus in the interval from 472 downhole to $731 \mathrm{~m}$ indicate the S. heteromorphus Zone (nannoplankton Zone NN5). Nannoplankton assemblages from this part of $\mathrm{Ng} 1$ contain high percentages (up to more than $90 \%$ ) of small reticulofenestrids: $R$. minuta and $R$. haqii. The following species also occur: $C$. pelagicus, $C$. mediterranea, C. floridanus, G. rotula, H. carteri, H. walbersdorfensis, Pontosphaera multipora, R. gelida, R. pseudoumbilica, Sphenolithus moriformis, Thoracosphaera spp., and $U$. jafari. In the lowermost part of NN5, from 675 to $731 \mathrm{~m}$ Helicosphaera waltrans occurs. This form was used for biostratigraphic subdivision of nannoplankton Zone NN5 into subzones by a few authors in the Mediterranean (Theodoridis 1984; Fornaciari et al. 1996) and Central Paratethys (Švábenická 2002) bioprovinces. The occurrences of $H$. waltrans were also reported from Lower Badenian (Lower Lagenidae Zone) sediments of the Styrian Basin (Rögl et al. 2002) and the Alpine-Carpathian Foredeep (Ćorić and Rögl 2004; Ćorić and Švábenická 2004). In the upper part of the Retznei section (Styrian Basin), H. waltrans co-occurs 
with Orbulina suturalis (Rögl, personal communication) within the Lower Lagenidae Zone. The Upper/Lower Lagenidae Zone boundary is placed approximately between the first occurrence (FO) of O. suturalis and LO of Praeorbulina sicana. The FO of H. waltrans in $\mathrm{Ng} 1$ can be dated as $15.47 \mathrm{Ma}$ (Abdul Aziz et al. 2008), whereas its LO can be presumed to be around 14.36 Ma (Abdul Aziz et al. 2008) (between FO of $O$. suturalis and LO of $P$. sicana, within the Lower Lagenidae Zone). Recent results indicate that $H$. waltrans disappears below the Lower/Upper Lagenidae Zone boundary in the Central Paratethys. H. ampliaperta co-occurs with $S$. heteromorphus in the $762.9 \mathrm{~m}$ sample. Therefore, this sample can be attributed to the H. ampliaperta Zone (nannoplankton Zone NN4). The accompanying taxa are $C$. pelagicus, $C$. mediterranea, C. floridanus, H. carteri, Helicosphaera scissura, H. walbersdorfensis, P. multipora, R. gelida, R. haqii, R. minuta, R. pseudoumbilica, S. moriformis, and U. jafari.

We used the latest calibration of Abdul Aziz et al. (2008) for the range of $H$. waltrans; it is much longer and seems to be more realistic than the earlier one after Lourens et al. (2004).

Abdul Aziz et al. (2008) give the following ages ["The bioevent ages through interpolation of subchron ages according to Astronomically Tuned Neogene Time Scale (ATNTS04)']:

\begin{tabular}{lll}
\hline S. heteromorphus & LO & $13.419+-7$ \\
\hline H. waltrans & LCO & $13.628+-3$ \\
\hline & LCO & $14.357+-4$ \\
\hline O. suturalis & FCO & $15.476+-5$ \\
\hline H. ampliaperta & FAD & $14.561+-4$ \\
\hline
\end{tabular}

LO, last occurrence; LCO, last common occurrence; FCO, first common occurrence; AS, abundance spike; FAD, first appearance datum.

The age of LAD of $S$. heteromorphus at $472 \mathrm{~m}$ in the $\mathrm{Ng} 1$ corehole is $13.53 \mathrm{Ma}$ (after Lourens et al. 2004), which fits well with the ages of LO and LCO of the species after Abdul Aziz et al. (2008).

Depths suggested for the zone/subzone boundaries are displayed in Fig. 2.

\section{Paleoecology}

Sediments from the upper part of the $H$. waltrans biohorizon and NN5 Zone contain high percentages of small reticulofenestrids ( $R$. minuta and $R$. haqii). The reconstructed oligotrophic paleoconditions of a well-stratified water column enabled the bloom of these small forms during this interval. 


\section{Paleo water depth}

Almost all samples taken from 433 to $612 \mathrm{~m}$ are dominated by epiphytic benthic foraminifera such as Asterigerinata planorbis, Cibicides lobatulus, Hansawaia boueana, and Heterolepa dutemplei, with the exception of the sample taken from $480.3 \mathrm{~m}$, dominated by Bulimina elongata. The dominating species are listed in Supplementary Material B. The species B. elongata is an inbenthic species living relatively deep in the sediment and profiting from high food availability, while able to tolerate dysoxic conditions. However, the majority of the samples are characterized by an epiphytic assemblage, where foraminifera were living on the blades or leaves of benthic plants. Although the benthic plants hardly ever fossilize, the epiphytic foraminiferal fauna reveals the presence of these plants and opens ways of paleoecological interpretations (Mateu-Vicens et al. 2010). More specifically, these benthic plants could have been seagrass or more likely benthic algae based on the foraminifera morphotypes present in the material (Langer 1993; Drinia et al. 2005; Mateu-Vicens 2014). This vegetation, providing a home to the epiphytic foraminifera, needs light for photosynthesis, directly indicating the maximum depth of deposition as inside the euphotic zone. In the present-day ocean, the light able to support vegetation penetrates $200 \mathrm{~m}$ at most, but optimum depth for benthic plants is even shallower, usually less than $50 \mathrm{~m}$ [e.g., A. planorbis; see Mendes et al. (2013), among others].

The paleo water depth estimation based on the presence of epiphytes was refined by using the corrected planktonic/benthic (P/B) ratio. Here, we followed the approach of van der Zwaan et al. (1990) as species level determination is less necessary in their corrected $\mathrm{P} / \mathrm{B}$ ratio then in the more recently published proxy of Hohenegger (2005) based on depth distribution of individual species. Results are displayed in Fig. 3.

The $\mathrm{P} / \mathrm{B}$ ratio shows a progressive decrease of the water depth from $140-120 \mathrm{~m}$ to about $40 \mathrm{~m}$ during deposition of the sediments penetrated in the 612 to $480 \mathrm{~m}$ interval. This shallowing trend is in accordance with the regionally observed uplift across the NN6/NN5 boundary (Filipescu and Girbacea 1997; Báldi et al. 2002). During the deposition of the rest of the studied sequence, the water depth was about $40 \mathrm{~m}$. This shallow depth is supported by the rather uniform fauna dominated by the epiphyte A. planorbis.

The estimated paleo water depth is not given for the sample at $479.3 \mathrm{~m}$, as the dominant species of the sample is B. elongata. This species lives deep in the sediment, where accumulated organic matter (OM) provides an ample food resource and is thus independent of the OM flux reaching the seafloor from surface water (Murray 2006).

Since soaking in hydrogen peroxide was not sufficient to disintegrate the samples from below $612 \mathrm{~m}$, it was not possible to calculate the $\mathrm{P} / \mathrm{B}$ ratio for the lower third of the interval studied. The Anomia-Cardium-Pitaria-Ostrea and Algae-Ostrea-Pecten assemblages observed between 612 and $642 \mathrm{~m}$ and at around $700 \mathrm{~m}$, respectively (Selmeczi et al. 2004) suggest shallow water sedimentation for the 612-697 m interval. 


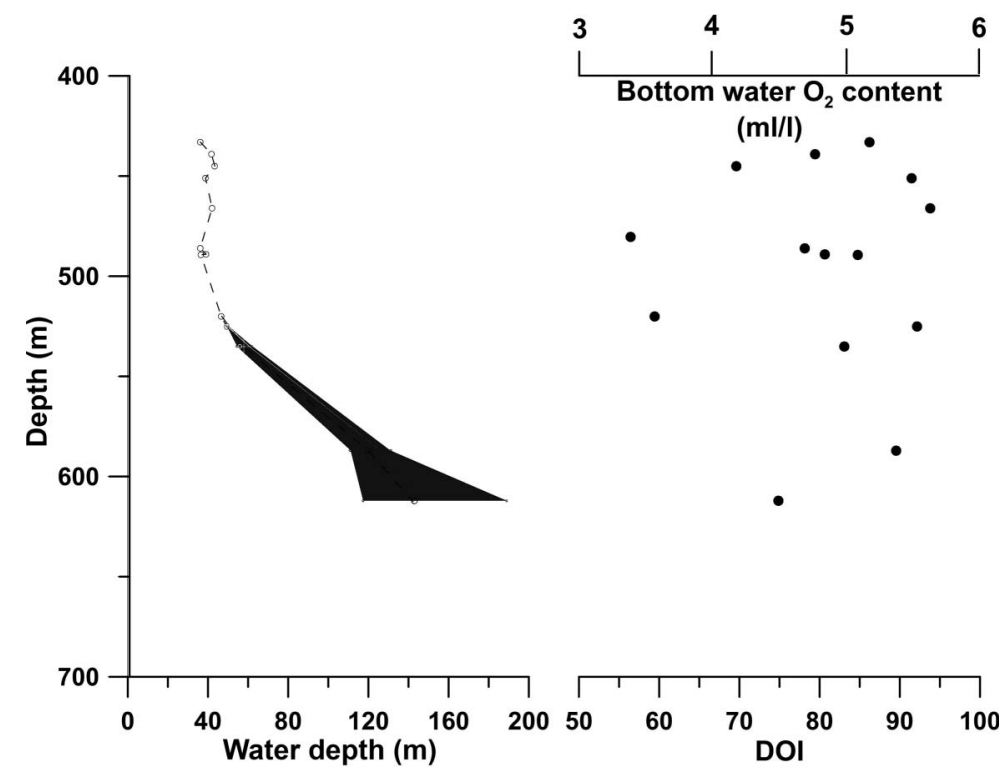

Fig. 3

Changes of water depth and bottom water oxygenation during deposition of the sediments penetrated in the 400-620 m depth interval, $\mathrm{Ng} 1$ corehole. Above $550 \mathrm{~m}$, the minimum and maximum water depth are practically identical. The darker belts represent the more probable depth interval. DOI: dissolved oxygen index of Kaiho (1994)

\section{Oxygen content of the bottom water}

The dissolved oxygen index (DOI) of Kaiho (1994) is used here for estimation of $\mathrm{O}_{2}$ content expressed in $\mathrm{ml} / \mathrm{l}$. The DOI was calculated in all possible ways (DOI*1-4) supposing all undetermined specimens to be all oxic, or none of them oxic, all dysoxic or none of them dysoxic. Values obtained are listed in Supplementary Material B and displayed in Fig. 3. All DOI values are higher than 50, falling into the category of "high oxic" according to Kaiho's classification (1994). Based on this proxy, the bottom was very well ventilated (minimum $3 \mathrm{ml} / 1$ dissolved $\mathrm{O}_{2}$ content) during deposition of the sediments penetrated above $612 \mathrm{~m}$.

The Anomia-Cardium-Pitaria-Ostrea assemblage observed in the $612-642 \mathrm{~m}$ interval (Selmeczi et al. 2004), the common presence of Amussium (Open File Report No. 1775/1) and the red alga containing limestone beds suggest that the sediments below $612 \mathrm{~m}$ were deposited in similarly oxygenated water.

\section{$O M$ and carbonate}

The TOC content, Rock-Eval parameters, the organic and inorganic $\delta^{13} \mathrm{C}$, and the carbonate content are listed in Table 1, while variations of some of these parameters along depth are displayed in Fig. 4. 
Table 1

Organic geochemical data, isotope ratios, and carbonate content (n.d. = not determined)

\begin{tabular}{|c|c|c|c|c|c|c|c|}
\hline Depth (m) & TOC $(\%)$ & $T_{\max }\left({ }^{\circ} \mathrm{C}\right)$ & $\begin{array}{c}\mathrm{HC}_{\text {pot }}(\mathrm{kg} \\
\mathrm{HC} / \mathrm{t})\end{array}$ & $\begin{array}{c}\mathrm{HI}(\mathrm{mg} \\
\mathrm{HC} / \mathrm{g} \\
\mathrm{TOC})\end{array}$ & $\begin{array}{c}\delta^{13} \mathrm{C}_{\text {org }} \\
(\% 0)\end{array}$ & $\begin{array}{c}\delta^{13} \mathrm{C}_{\mathrm{carb}} \\
(\% \mathrm{o})\end{array}$ & $\begin{array}{c}\text { Carbonate } \\
(\%)\end{array}$ \\
\hline 404.00 & 0.360 & 422 & 0.87 & 219 & n.d. & n.d. & 63.99 \\
\hline 415.00 & 0.320 & 423 & 0.91 & 253 & n.d. & n.d. & 73.64 \\
\hline 418.00 & 0.320 & 425 & 1.20 & 331 & n.d. & n.d. & 86.36 \\
\hline 424.00 & 0.910 & 424 & 2.41 & 247 & n.d. & n.d. & 62.95 \\
\hline 433.00 & 1.120 & 417 & 2.30 & 188 & -20.10 & 0.80 & 60.91 \\
\hline 436.00 & 1.420 & 422 & 2.45 & 162 & n.d. & n.d. & 66.82 \\
\hline 439.00 & 1.320 & 426 & 3.65 & 256 & n.d. & n.d. & 66.36 \\
\hline 445.00 & 0.240 & 400 & 0.66 & 231 & -20.30 & 0.20 & 16.86 \\
\hline 451.00 & 1.070 & 422 & 2.79 & 243 & -19.80 & 0.90 & 67.73 \\
\hline 454.00 & 0.850 & 422 & 2.01 & 220 & n.d. & n.d. & 81.99 \\
\hline 460.00 & 1.040 & 425 & 2.52 & 222 & n.d. & n.d. & 73.64 \\
\hline 466.00 & 0.940 & 427 & 2.93 & 288 & -20.30 & 1.00 & 81.59 \\
\hline 472.00 & 0.300 & 396 & 0.83 & 213 & n.d. & n.d. & 84.77 \\
\hline 480.00 & 0.370 & 410 & 0.90 & 207 & n.d. & n.d. & 39.32 \\
\hline 486.00 & 1.160 & 428 & 3.26 & 262 & -19.30 & 1.70 & 74.55 \\
\hline 489.00 & 0.950 & 423 & 3.53 & 347 & -20.20 & 1.50 & 76.14 \\
\hline 492.00 & 0.990 & 424 & 3.51 & 330 & n.d. & n.d. & 80.00 \\
\hline 495.00 & 0.860 & 426 & 3.76 & 410 & n.d. & n.d. & 78.86 \\
\hline 497.00 & 0.620 & 425 & 2.76 & 412 & n.d. & n.d. & 84.77 \\
\hline 520.00 & 1.360 & 420 & 3.61 & 247 & -17.70 & 1.90 & 77.27 \\
\hline 525.00 & 0.860 & 429 & 3.75 & 408 & -19.00 & 1.60 & 78.41 \\
\hline 535.00 & 0.780 & 425 & 2.59 & 310 & -17.50 & 1.80 & 71.82 \\
\hline 545.00 & 0.330 & 428 & 2.97 & 806 & n.d. & & 91.99 \\
\hline 550.00 & 1.020 & 423 & 3.47 & 316 & -19.71 & 0.60 & 85.68 \\
\hline 555.00 & 0.360 & 421 & 1.01 & 256 & -20.49 & 0.13 & 95.00 \\
\hline 565.00 & 0.880 & 420 & 2.80 & 292 & -20.86 & 0.55 & 81.99 \\
\hline 575.00 & 1.430 & 421 & 4.76 & 306 & -19.70 & 0.59 & 87.95 \\
\hline
\end{tabular}


Table 1 (continued)

\begin{tabular}{|c|c|c|c|c|c|c|c|}
\hline Depth (m) & TOC (\%) & $T_{\max }\left({ }^{\circ} \mathrm{C}\right)$ & $\begin{array}{c}\mathrm{HC}_{\text {pot }}(\mathrm{kg} \\
\mathrm{HC} / \mathrm{t})\end{array}$ & $\begin{array}{c}\mathrm{HI}(\mathrm{mg} \\
\mathrm{HC} / \mathrm{g} \\
\mathrm{TOC})\end{array}$ & $\begin{array}{c}\delta^{13} C_{\text {org }} \\
(\% o)\end{array}$ & $\begin{array}{c}\delta^{13} \mathrm{C}_{\text {carb }} \\
(\% \mathrm{o})\end{array}$ & $\begin{array}{c}\text { Carbonate } \\
(\%)\end{array}$ \\
\hline 583.00 & 1.150 & 419 & 3.61 & 286 & -20.20 & 0.45 & 82.73 \\
\hline 587.00 & 1.600 & 427 & 5.65 & 331 & n.d. & n.d. & 83.86 \\
\hline 591.30 & 0.060 & 403 & 0.20 & 262 & n.d. & n.d. & 98.99 \\
\hline 596.00 & 0.800 & 423 & 4.66 & 532 & n.d. & n.d. & 83.41 \\
\hline 608.00 & 1.360 & 419 & 4.05 & 272 & -19.95 & 0.94 & 83.86 \\
\hline 612.00 & 1.420 & 423 & 3.97 & 258 & -20.90 & 0.70 & 72.95 \\
\hline 620.00 & 1.250 & 423 & 4.20 & 308 & n.d. & & 81.59 \\
\hline 625.00 & 0.950 & 416 & 2.45 & 233 & -21.09 & 0.62 & 77.73 \\
\hline 645.00 & 1.550 & 418 & 4.26 & 249 & -20.98 & 0.92 & 66.14 \\
\hline 648.60 & 0.070 & 364 & 0.13 & 96 & n.d. & & 44.32 \\
\hline 655.00 & 1.120 & 414 & 2.17 & 175 & -21.81 & 1.00 & 62.27 \\
\hline 665.00 & 0.280 & 389 & 0.68 & 158 & n.d. & n.d. & 27.50 \\
\hline 675.00 & 1.930 & 422 & 7.02 & 332 & n.d. & n.d. & 63.99 \\
\hline 680.00 & 1.600 & 419 & 4.15 & 235 & -20.86 & 0.20 & 68.64 \\
\hline 691.00 & 1.760 & 417 & 5.35 & 278 & n.d. & n.d. & 70.45 \\
\hline 697.00 & 0.700 & 419 & 1.92 & 252 & n.d. & n.d. & 55.91 \\
\hline
\end{tabular}

The amount of carbonate expressed in $\mathrm{CaCO}_{3}$ varies mostly between $40 \%$ and $95 \%$. It increases upward in the lower $120 \mathrm{~m}$ of the section, then decreases in its upper part. carbonate content shows a high scatter in the lower $120 \mathrm{~m}$ and the upper $100 \mathrm{~m}$. Some samples, lying beyond the above depth trends, contain only $20-30 \%$ carbonate.

TOC varying between $0.4 \%$ and $2 \%$ decreases upward with a great scatter in the lower half of the section, then does not show a definite depth trend (Fig. 4).

$T_{\max }$ varying between 410 and $429{ }^{\circ} \mathrm{C}$ clearly shows that the kerogen is immature. HI shows a co-variance with the carbonate content and ranges between 150 and $350 \mathrm{mg} \mathrm{HC} / \mathrm{g}$ TOC in the great majority of the samples; hence, they contain mostly Type II/III and Type II kerogen (Fig. 4).

The $\delta^{13} \mathrm{C}_{\text {org }}$ ranges between $-22 \%$ and $-17.5 \%$ (Fig. 4); in the lower half of the section, it moderately increases upward. Then, after a shift of 2.2\%o between 555 and $520 \mathrm{~m}$, it shows a marked decrease. 


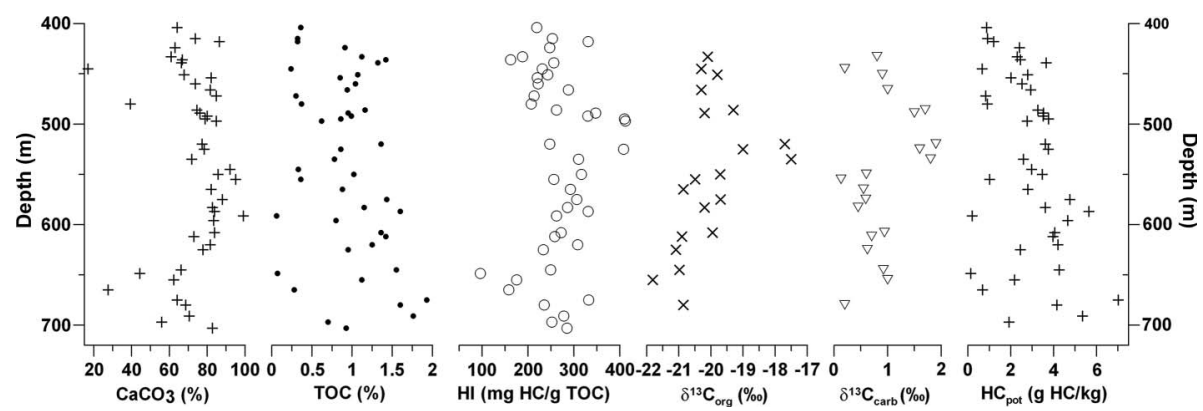

Fig. 4

Variations with depth of carbonate content, Rock-Eval indices, $\mathrm{HC}_{\text {pot }}$, and organic and inorganic $\mathrm{C}$-isotope ratios, 400-700 $\mathrm{m}$ depth interval, $\mathrm{Ng} 1$ corehole

The $\delta^{13} \mathrm{C}_{\text {carb }}$ ranges between $0.13 \%$ and $1.90 \%$; in the lower half of the section, it slowly decreases upward. Then, after a 1.2\%o jump between 555 and $520 \mathrm{~m}$, it shows a marked decrease (Fig. 4).

\section{Hydrocarbon potential}

A significant part of the samples shows $\mathrm{HC}_{\text {pot }}$ and TOC values above $3 \mathrm{~kg} \mathrm{HC} / \mathrm{t}$ and 1\%, respectively (Fig. 4). According to Peters and Cassa (1994), these samples represent fair oil source rocks.

Taking into account that for carbonate oil source rocks $0.4 \%$ is the lower limit of TOC content (Palacas 1978), an even higher portion of the samples, being mostly in the carbonate dominated 625-454 m depth interval, represents fair or even good oil source rocks.

\section{Discussion}

\section{Relative weights of the kerogen precursors}

The relatively high HI values - they are below $200 \mathrm{mg} \mathrm{HC} / \mathrm{g}$ TOC in only $10 \%$ of the samples, while in more than $30 \%$ of them they are above $300 \mathrm{mg} \mathrm{HC} / \mathrm{g}$ TOC - suggest that in the studied section, marine OM is at least one of the main sources of the kerogen. The common occurrence of epiphytic foraminifera living on benthic algae (see Paleo Water Depth subsection) confirms that beyond phytoplankton, benthic algae have also contributed to some degree to the kerogen. On the other hand, in view of the proximity of the dry land, some admixture of terrestrial plant matter must also be assumed. Pollen and terrestrial plant debris observed in significant amount in the palynological concentrates of four samples studied from the 400-700 m depth interval support this premise (Vetö 1973). 
Isotopic studies carried out on recent plants (Deines 1980; Meyers 1994; Reuning et al. 2005) revealed that marine benthic plants, marine phytoplankton, and land plants typically exhibit $\delta^{13} \mathrm{C}_{\text {org }}$ values between $-12 \%$ and $-5 \%$, $-22 \%$ and $-20 \%$, and $-26 \%$ and $-25 \%$, respectively.

Although the massive contribution of isotopically very light terrestrial plant matter is obvious, $\delta^{13} \mathrm{C}_{\text {org }}$ is less negative than $-22 \%$ in all of the samples studied and even less negative than $-20 \%$ in some of them. This finding strongly suggests that the isotopically very heavy benthic algal material was an important kerogen precursor.

In the following, a semi-quantitative estimation of the benthic algal contribution to the kerogen is attempted. Since no Rock-Eval and $\delta^{13} C_{\text {org }}$ data are available from immature Badenian sediments of the Zala Basin, corresponding data reported from nearby Austrian basins are used for this purpose.

According to Reischenbacher et al. (2007), the HI of the great majority of the 40 samples studied from an immature marine Badenian section of the Lavanttal Basin (Austria) is significantly lower than $100 \mathrm{mg} \mathrm{HC} / \mathrm{g}$ TOC, and their kerogen is of predominantly terrestrial origin. Similarly, Wagreich et al. (2008) report HI ranging between 30 and $90 \mathrm{mg} \mathrm{HC} / \mathrm{g}$ TOC from the immature marine Badenian of the BadenSoos section, Vienna Basin, containing kerogen of predominantly terrestrial origin.

The average and range of $\delta^{13} \mathrm{C}_{\text {org }}$ of 10 samples studied by Johns and Hoefs (1985) from the immature marine Badenian of the well Aderkla 78 (Vienna Basin) are $-24.7 \%$ and $-25.8 \%$ o to $-23.7 \%$, respectively. The kerogen of these samples is also dominated by terrestrial components.

In the following, the kerogen of the Badenian samples studied from the $\mathrm{Ng} 1$ core is considered as a mixture of terrestrial and marine end-members. For the calculations, $60 \mathrm{mg} \mathrm{HC} / \mathrm{g}$ TOC and $-24.7 \%$ will be used for $\mathrm{HI}$ and $\delta^{13} \mathrm{C}_{\text {org }}$ of the terrestrial endmember, respectively, while $408 \mathrm{mg} \mathrm{HC} / \mathrm{g}$ TOC, the greatest $\mathrm{HI}$ found on the $\mathrm{Ng} 1$ samples analyzed for $\delta^{13} \mathrm{C}_{\text {org }}$ (Table 1), will be used for $\mathrm{HI}$ of the marine one.

Applying a simple mixing model (Fig. 5a), we have determined that the marine end-member represents $35-75 \%$ of the kerogen in the great majority of the $\mathrm{Ng} 1$ samples, studied for $\delta^{13} \mathrm{C}_{\text {org }}$.

In the second step, we assessed the $\delta^{13} \mathrm{C}_{\text {org }}$ of the marine end-member, using in the calculations $-24.7 \%$ for $\delta^{13} \mathrm{C}_{\text {org }}$ of the terrestrial end-member and the relative weights of the marine end-member obtained above. The obtained values range between $-19.2 \%$ and $-11.7 \%$.

Supposing that benthic algal and planktonic components of the kerogen have the same $\mathrm{HI}$, and using $-8.5 \%$ and $-21 \%$ or their $\delta^{13} \mathrm{C}$, we can assess their relative weights in the marine end-member. We have found that benthic algal components represent $20-55 \%$ of the marine end-member of the kerogen in the great majority of the $\mathrm{Ng} 1$ samples, studied for $\delta^{13} \mathrm{C}_{\text {org }}$ (Fig. 5b). We believe that in spite of the obvious simplifications applied in the above calculations, the obtained results give a good idea of the relative weight of benthic algal material in the marine, oil-forming part of the kerogen. 

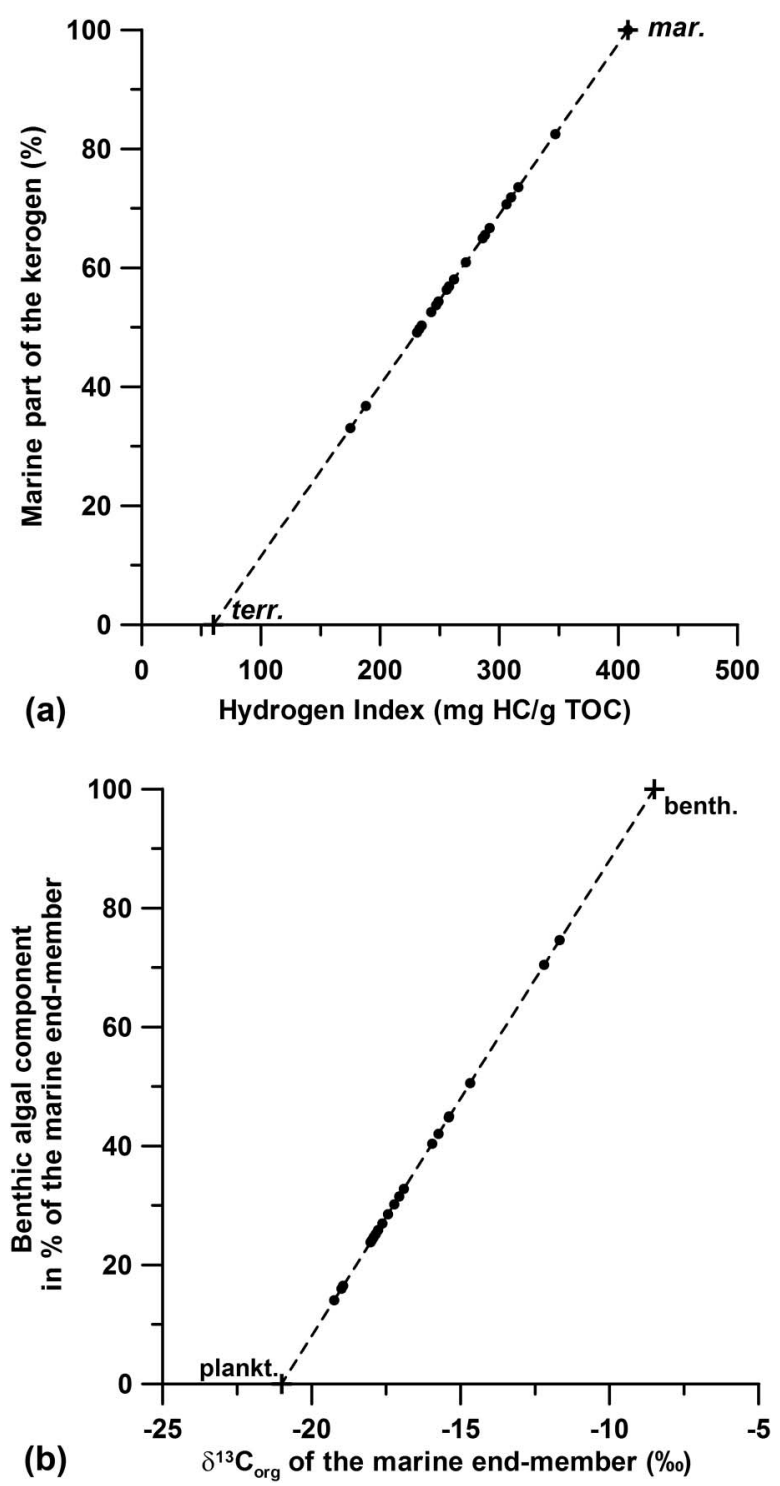

Fig. 5

(a) Amount of marine components expressed in percentage of kerogen (dashed line: mixing line of the terrestrial and marine kerogen end-members). (b) Amount of benthic algal component expressed in percentage of marine kerogen (dashed line: mixing line of the benthic algal and planktonic kerogen end-members) 
The depositional environment and its control on carbon isotopy and preservation of the kerogen

Planktonic productivity, bottom water $\mathrm{O}_{2}$ content, and mass accumulation rate (MAR) are considered as of prime importance for the formation of oil source rocks (see Littke et al. 1997 and references therein).

Since sediments of the 700-450 m depth interval were deposited from oligotrophic water, poor in nutrients (see above), planktonic productivity was certainly low during the corresponding time.

The bottom water was rich in $\mathrm{O}_{2}$ during deposition of the sediments of the 700-400 m depth interval (see Oxygen Content of the Bottom Water subsection).

MAR was calculated for three parts of the studied section using nannoplankton zone/subzone ages documented in the section on Biostratigraphy and $2.17 \mathrm{~g} / \mathrm{cm}^{3}$ for dry density of the sediments (Dudko and Ódor 1980). The obtained values, expressed in weight of dry sediment deposited on a unit area of bottom by time, are listed in Table 2.

High $\mathrm{O}_{2}$ content of the bottom water is commonly considered as enhancing degradation of the freshly deposited OM (e.g., Canfield 1994 and references therein) and the oligotrophic conditions prevailing during deposition of the bulk of the section studied suggest a relatively low flux of planktonic remains to the bottom. Hence, the trophic status of the sea and the redox conditions of the bottom both worked against the formation of oil source rocks.

On the other hand, the high MAR (Table 2) was certainly favorable for preservation of the freshly deposited OM (e.g., Canfield 1994 and references therein) and in this way, for formation of oil source rocks. In view of the high carbonate content of the studied section (Table 1), the documented high MAR implies high rate of carbonate deposition as well. It is worth noting that the intense benthic algal life was certainly accompanied by intense carbonate precipitation, thus enhancing the preservation of the OM.

Table 2

Mass accumulation rates during the NN6 and NN5 nannoplankton zones

\begin{tabular}{lccccc}
\hline $\begin{array}{l}\text { Nannoplankton } \\
\text { zone/subzone })\end{array}$ & $\begin{array}{c}\text { Depth } \\
\text { interval } \\
(\mathrm{m})\end{array}$ & $\begin{array}{c}\text { Age } \\
\text { boundaries } \\
(\mathrm{Ma})\end{array}$ & $\begin{array}{c}\text { Duration } \\
(\mathrm{Ma})\end{array}$ & $\begin{array}{c}\text { Average } \\
\text { SR } \\
(\mathrm{m} / \mathrm{Ma})\end{array}$ & $\begin{array}{c}\text { Average } \\
\text { MAR } \\
\left(\mathrm{t} / \mathrm{m}^{2} / \mathrm{Ma}\right)\end{array}$ \\
\hline NN6 & $454-350.7$ & $13.53-12.7^{*}$ & Max. 0.83 & Min. 124 & Min. 269 \\
\hline Upper part of NN5 & $665-454$ & $14.36-13.53$ & 0.83 & 254 & 551 \\
\hline H. waltrans & $747-665$ & $14.91-14.36$ & 0.55 & 149 & 323 \\
\hline
\end{tabular}

*12.7 $\mathrm{Ma}$ is the age assigned to the beginning of Sarmatian regional stage. Since the contact between Sarmatian and Badenian is of discordant nature (see Geologic Setting section), it is probable that sediments penetrated between 454 and $350.7 \mathrm{~m}$ do not represent the entire NN6; hence, the corresponding average SR and MAR are likely minimum values 
The isotopic composition of the dissolved inorganic carbon (DIC) obviously exerted strong control on that of the phytoplankton and the benthic algae. On the other hand, it is commonly admitted that $\delta^{13} \mathrm{C}$ of the syngenetic carbonate closely reflects isotopic composition of the DIC.

In spite of some admixture of diagenetic carbonate (e.g., foraminifera lining; see Preparation and Determination of Foraminifera subsection), the bulk of the high carbonate content of the studied samples is certainly of syngenetic origin, preserving the isotopic signal of the DIC. Hence, variation of $\delta^{13} \mathrm{C}_{\text {carb }}$ along the section reflects changes of the isotopic composition of DIC occurred during its deposition. For this reason, an analysis of the relationship between depth trends of $\delta^{13} \mathrm{C}_{\text {carb }}$ and $\delta^{13} \mathrm{C}_{\text {org }}$ (Fig. 4) is promising for a better understanding of the cause(s) of variation observed in carbon isotopic composition of the kerogen.

$\delta^{13} \mathrm{C}_{\text {carb }}$ shows a $<1 \%$ upward decrease between 655 and $555 \mathrm{~m}$, suggesting that a similar decrease of the DIC $\delta^{13} \mathrm{C}$ took place during deposition of the corresponding sediments. On the other hand, $\delta^{13} \mathrm{C}_{\text {org }}$ shows an about $1.5 \%$ upward increase in the same depth interval.

For interpreting these opposite isotopic trends, at least two factors must be taken into account:

(a) The slight upward increase of HI in the 655-555 $\mathrm{m}$ depth interval (Fig. 4) makes likely an upward decreasing contribution of the isotopically relatively light land plant components to the OM.

(b) The shallowing of the sea during deposition of the sediments of the 612-555 m depth interval (Fig. 3) made progressively easier the access of sunlight to the bottom, resulting in an intensification of the benthic photosynthesis. Hence, an upward increasing contribution of the isotopically very heavy benthic algal matter can be expected in the corresponding depth interval.

The enrichment of DIC in ${ }^{12} \mathrm{C}$ was not able to counterbalance the overall isotopic effect of these two factors.

The $\delta^{13} \mathrm{C}_{\text {carb }}$ excursion between 555 and $520 \mathrm{~m}$ records an approximately $1.2 \%$ enrichment of the DIC in ${ }^{13} \mathrm{C}$. The $2 \%$ increase of $\delta^{13} \mathrm{C}_{\text {org }}$ observed in this depth interval is at least partly caused by this shift in DIC isotopic composition. In this depth interval, HI does not show a clear trend (Fig. 4); the cause of the difference between the organic and inorganic carbon isotope shifts is unknown. We note that Báldi (2006) and Gonera et al. (2000) studying the carbon isotope composition of foraminifera from sediments deposited during the NN5 biozone in two sections of the Central Paratethys, did not find such an excursion. Hence, this was a local phenomenon and its interpretation is beyond the scope of this work.

Finally, the well pronounced upward decrease of $\delta^{13} \mathrm{C}_{\text {carb }}$ above $520 \mathrm{~m}$ is accompanied by an even stronger upward decrease of $\delta^{13} \mathrm{C}_{\text {org }}$. The difference between the organic and inorganic carbon isotope shifts can be explained by an upward 
increasing relative weight of the isotopically light land plant matter, suggested by the upward decrease of HI (Fig. 4).

\section{Regional significance}

Holczhacker et al. (1981) report that the third of a sample set (70 samples), representing the marine Middle Miocene of the Hungarian part of the PBS, contains kerogen with $\delta^{13} \mathrm{C}$ ranging between $-22 \%$ and $-18 \%$ or even less negative. According to the same authors, the $\delta^{13} \mathrm{C}$ of the chloroform-soluble bitumen extracted from the third of the Middle Miocene marine sediments (60 samples) studied from Hungary is less negative than $-24 \%$. Hence, the very heavy organic C-isotopic composition of the $\mathrm{Ng} 1$ Badenian sediments is not a pure curiosity, and benthic algae likely are important kerogen precursors in the marine Middle Miocene of the PBS.

Koncz (1990) reports that some oils of the Zala Basin are characterized by high pristane/phytane ratio (1.95-3.46) and relatively heavy $\mathrm{C}$-isotopic composition $\left(\delta^{13} \mathrm{C}\right.$ of the saturate fraction ranges between $-23.5 \%$ and $-21 \%$ ). Based on these indices and by making comparison with extracts of marine Middle Miocene sediments, Koncz (1990) and Clayton and Koncz (1994) think that the latter are the likely source rocks of the oils.

Since pristane/phytane ratio above 1 is commonly considered as an index for deposition from oxic bottom water and the very heavy $\mathrm{C}$-isotopic composition of the saturate fraction suggests that benthic algal matter acted as source for the oils, we think that Middle Miocene source rocks, deposited under similar conditions as the $\mathrm{Ng} 1$ Badenian sediments, produced oil in commercial quantity in the Zala Basin.

\section{A novel approach for recognition/estimation of benthic algal contribution to kerogen}

Due to the poor fossilization potential of the benthic algae, it is difficult to study them in sedimentary rocks by microscopic techniques. As far as we know the significant contribution of benthic algae to kerogen has been suggested only for Jurassic and Miocene source rocks of some northwest Chinese basins. Li et al. (2012) speculated about the massive presence of benthic algae in the Miocene source rocks of the Tarim Basin, but their suggestion is not supported by data. Cao et al. (2009) reported UV-microscopic observations of red algal material and elevated concentration of the diahopane biomarker as independent lines of evidence for the contribution of benthic algae to the kerogen of different Jurassic source rocks of the Qaidam Basin.

The original goal of this study was to contribute to a better understanding of the depositional environment of the Miocene source rocks in the PBS. For this purpose, a new approach was followed using combined micropaleontological, organic geochemical, and isotopic techniques. 
In the course of the work, we found that if we use these independent techniques, especially the combined study of benthic foraminifera and measurement of $\delta^{13} \mathrm{C}_{\text {org }}$, we are able to estimate, at least semi-quantitatively, the weight of the benthic algal material in the kerogen.

Our combined paleontological, organic geochemical, and isotopic results provide the first sound demonstration of major benthic algal contribution to oil-prone kerogen. This simple new multi-proxy approach seems to be promising for a better understanding of the formation of oil source rocks in carbonate-dominated shelf environment.

\section{Conclusions}

Benthic algae represent $20-55 \%$ of the marine kerogen in the Badenian section studied from the $\mathrm{Ng} 1$ core. Benthic algae are important kerogen precursors in effective oil source rocks in the Middle Miocene of Hungary. The combined study of benthic foraminifera, carbon isotopic composition of kerogen, and Rock-Eval indices is a powerful multi-proxy approach for recognition/assessment of contribution of benthic algae to kerogen.

\section{Acknowledgements}

This study was funded by grants of the Hungarian Scientific Foundation (OTKA T 032260 and D 42191). Discussions with and comments of Mária Báldi-Beke, Margit Bohn-Havas, András Németh, and Ildikó Selmeczi are gratefully acknowledged. We would like to thank two anonymous reviewers for suggestions and remarks.

\section{References}

Abdul Aziz, H., A. Di Stefano, L.M. Foresi, F.J. Hilgen, S.M. Iaccarino, K.F. Kuiper, F. Lirer, G. Salvatorini, E. Turco 2008: Integrated stratigraphy and 40Ar/39Ar chronology of early Middle Miocene sediments from DSDP Leg 42A, Site 372 (western Mediterranean). - Palaeogeography, Palaeoclimatology, Palaeoecology, 257, pp. 123-138.

Alajbeg, A., V. Britvić, S. Švel-Cerovečki, C. Cornford, A. Todorić, J. Rajković, G. Barić, A. Putniković 1990: Geochemical study of the oils and source rocks in the Pannonian Basin (Yugoslavia). - Organic Geochemistry, 16, pp. 339-352.

Alajbeg, A., M. Moldowan, G.J. Demaison, V. Jelaska, Z. Brodic-Jakupak, D. Svilković, B. Huizinga 1996: Geochemical study of oils and oil source rocks from the Eastern Drava and Slavonija-Srijem depressions, Pannonian Basin, Croatia. - Geologica Croatica, 49, pp. 135-143.

Badics, B., I. Vetö 2012: Source rocks and petroleum systems in the Hungarian part of the Pannonian Basin: The potential for shale gas and shale oil plays. - Marine and Petroleum Geology, 31, pp. 53-69.

Badics, B., A. Uhrin, I. Vető, A. Bartha, Cs. Sajgó 2011: Basin-centered gas in the Makó Trough, Hungary: A 3D basin and petroleum system modelling investigation. - Petroleum Geoscience, 17, pp. 405-416. 
Báldi, K. 2006: Paleoceanography and climate of the Badenian Central Paratethys (Middle Miocene 16.4-13.0 Ma) based on foraminifera and stable isotope evidence. - International Journal of Earth Sciences, 95, pp. 119-142.

Báldi, K., L. Benkovics, O. Sztanó 2002: Badenian (Middle Miocene) basin development in SW Hungary: Geohistory based on quantitative paleobathymetry of foraminifera. - International Journal of Earth Sciences, 91, pp. 490-504.

Barić, G., I. Mesić, M. Jungwirth 1998: Petroleum geochemistry of the deep part of the Drava depression, Croatia. - Organic Geochemistry, 29, pp. 571-582.

Barić, G., Z. Ivković, R. Perica 2000: The Miocene petroleum system of the Sava Depression, Croatia. Petroleum Geoscience, 6, pp. 165-173.

Canfield, D.E. 1994: Factors influencing organic carbon preservation in marine sediments. - Chemical Geology, 114, pp. 315-329.

Cao, J., L.Z. Bian, K. Hu, L.Q. Wang, S.Y. Yang, Y. Chen, X.Q. Peng 2009: Benthic macro red alga: A new possible bio-precursor of Jurassic mudstone source rocks in the northern Qaidam Basin, northwestern China. - Science in China Series D: Earth Science, 52, pp. 647-654.

Clayton, J.L., I. Koncz 1994: Petroleum geochemistry of the Zala Basin, Hungary. - AAPG Bulletin, 78, pp. $1-22$.

Clayton, J.L., I. Koncz, J.D. King, E. Tatár 1994: Organic geochemistry of crude oils and source rocks, Békés Basin. - In: Teleki, P.G., R.E. Mattick, J. Kókai (Eds): Basin Analysis in Petroleum Exploration. Kluwer Academic Publishers, The Netherlands, pp. 161-185.

Ćorić, S., F. Rögl 2004: Roggendorf-1 borehole, a key section for lower Badenian transgressions and the stratigraphic position of the Grund Formation (Molasse Basin, Lower Austria). - Geologica Carpatica, 55, pp. $165-178$.

Ćorić, S., L. Švábenická 2004: Calcareous nannofossil biostratigraphy of the Grund Formation (Molasse Basin, Lower Austria). - Geologica Carpatica, 55, pp. 147-153.

Deines, P. 1980: The isotopic composition of reduced carbon. - In: Fritz, P., J.C. Fontes (Eds): Handbook of Environmental Isotope Geochemistry. Elsevier, Amsterdam, pp. 329-406.

Drinia, H., E. Koskeridou, A. Antonarakou 2005: Late Pliocene benthic foraminifera and molluscs from the Atsipades Section, Central Crete: Paleoecological distribution and use in paleoenvironmental assessment. - Geobios, 38, pp. 315-324.

Dudko, A., L. Ódor 1980: A betemetődési mélység és a kompakciós víz mennyiségének becslése a térfogatsúly értékek segítségével, Dunántúli Középhegység (Estimation of the depth of burial and the amount of compaction water using rock density, Transdanubian Central Range). - Annual Report of the Hungarian Geological Institute, 1978, pp. 291-299. (in Hungarian)

Fekete, J., Cs. Sajgó, A. Demény 2010: Hydrogen isotope type-curves of very hot crude oils. - Rapid Communications in Mass Spectrometry, 25, pp. 191-198.

Filipescu, S., R. Girbacea 1997: Lower Badenian sea-level drop on the western border of the Transylvanian Basin: Foraminiferal paleobathymetry and stratigraphy. - Geologica Carpatica, 48, pp. 325-334.

Fornaciari, E., A. Di Stefano, D. Rio, A. Negri 1996: Middle Miocene quantitative calcareous nannofossil biostratigraphy in the Mediterranean region. - Micropaleontology, 42, pp. 37-63.

Gonera, M., T.M. Peryt, T. Durakiewicz 2000: Biostratigraphical and paleoenvironmental implications of isotopic studies $(18 \mathrm{O}, 13 \mathrm{C})$ of Middle Miocene (Badenian) foraminifers in the Central Paratethys. Terra Nova, 12, pp. 231-238.

Hasenhüttl, C., M. Kraljic, R.F. Sachsenhofer, B. Jelen, R. Rieger 2001: Source rocks and hydrocarbon generation in Slovenia (Mura Depression, Pannonian Basin). - Marine and Petroleum Geology, 18, pp. 115-132.

Hohenegger, J. 2005: Estimation of environmental paleogradient values based on presence/absence data: A case study using benthic foraminifera for paleodepth estimation. - Palaeogeography, Palaeoclimatology, Palaeoecology, 217, 115-130.

Holczhacker, K., I. Koncz, I. Fisch 1981: A stabilszénizotóparány-adatok felhasználási lehetőségei (Possible use of stable carbon isotope data). - Köolaj és Földgáz, 14, pp. 178-187. (in Hungarian) 
Horváth, F., L. Royden 1981: Mechanism for the formation of the intra-Carpathian basins: A review. - Earth Evolution Science, 1, pp. 307-316.

Johns, W.D., J. Hoefs 1985: Maturation of organic matter in Neogene sediments from the Aderklaa oilfield, Vienna Basin, Austria. - Mineralogy and Petrology, 34, pp. 143-158.

Kaiho, K. 1994: Benthic foraminiferal dissolved-oxygen index and dissolved oxygen levels in the modern ocean. - Geology, 22, pp. 719-722.

Király, A., K. Milota, I. Magyar, K. Kiss 2011: Tight gas exploration in the Pannonian Basin. - In: Vining, B.A., S.C. Pickering (Eds): Petroleum Geology: From Mature Basins to New Frontiers: Proceedings of the 7th Petroleum Geology Conference. Geological Society, London, pp. 1125-1129.

Koncz, I. 1990: Nagylengyel és környéke kőolaj-előfordulásainak eredete (The origin of the oil occurrences of Nagylengyel). - Általános Földtani Szemle, 25, pp. 55-82. (in Hungarian)

Ladwein, H.W. 1988: Organic geochemistry of the Vienna Basin: Model for hydrocarbon generation in overthrust belts. - AAPG Bulletin, 72, pp. 586-599.

Langer, M.R. 1993: Epiphytic foraminifera. - Marine Micropaleontology, 20, pp. 235-265.

Li, W., Z. Zhang, Y. Li, N. Fu, Y. Huang, L. Zan, H. Zhang 2012: The formation environment and development modes of Cenozoic source rocks in the Qiongdongnan Basin. - Chinese Journal of Geochemistry, 31, pp. 431-440.

Littke, R., D.R. Baker, J. Rullkötter 1997: Deposition of petroleum source rocks. - In: Welte, D.H., B. Horsfield, D.R. Baker (Eds): Petroleum and Basin Evolution. Springer. pp. 273-333.

Lourens, L., F. Hilgen, N.J. Shackleton, J. Laskar, J. Wilson 2004: Orbital tuning calibrations and conversions for the Neogene Period. - In: Gradstein, F.M., J.O. Ogg, A.G. Smith (Eds): A Geologic Time Scale 2004. Cambridge University Press, pp. 469-484.

Lučić, D., B. Saftić, K. Krizmanić, E. Prelogović, V. Britvić, I. Mesić, J. Tadej 2001: The Neogene evolution and hydrocarbon potential of the Pannonian Basin in Croatia. - Marine and Petroleum Geology, 18, pp. $133-147$.

Magyar, I., Gy. Juhász, A. Szuromi-Korecz, M. Sütő-Szentai 2004: A pannónai Tótkomlósi Mészmárga Tagozat kifejlődése és kora a Battonya-pusztaföldvári-hátság környezetében (The Tótkomlós Calcareous Marl Member of the Lake Pannon sedimentary sequence in the Battonya-Pusztaföldvár region, SE Hungary). - Földtani Közlöny, 133, pp. 521-540. (in Hungarian)

Malvić, T., A. Majstorović-Busić 2012: Unconventional hydrocarbon resources of the Bjelovar Subdepression (Pannonian Basin System) in Croatia: An overview. - Geologica Carpathica, 63, pp. 483-489.

Martini, E. 1971: Standard tertiary and quaternary calcareous nannoplankton zonation. - In: Farinacci, A. (Ed): Proceedings of the II Planktonic Conference. Roma, Italy, pp. 739-785.

Mateu-Vicens, G. 2014: Epiphytic foraminiferal indices as bioindicators in Mediterranean seagrass meadows. - Journal of Foraminiferal Research, 44, pp. 325-339.

Mateu-Vicens, G., A. Box, S. Deudero, B. Rodriguez 2010: Comparative analysis of epiphytic foraminifera in sediments colonized by seagrass Posidonia oceanica and invasive macroalgae Caulerpa spp. Journal of Foraminiferal Research, 40, pp. 134-147.

McCrea, J.M. 1950: On the isotope chemistry of carbonates and a paleotemperature scala. - The Journal of Chemical Physics, 18, pp. 849-857.

Mendes, I., J.A. Dias, J.O. Schönfeld, Ó. Ferreira, F. Rosa, F.J. de Lobo 2013: Living, dead and fossil benthic foraminifera on a river dominated shelf (northern Gulf of Cadiz) and their use for paleoenvironmental reconstruction. - Continental Shelf Research, 68, pp. 91-111.

Meyers, P.A. 1994: Preservation of elemental and isotopic source identification of sedimentary organic matter. - Chemical Geology, 114, pp. 289-302.

Murray, J.W. 2006: Ecology and Applications of Benthic Foraminifera. - Cambridge University Press, 440 p.

Palacas, J.G. 1978: Preliminary assessment of organic matter content and petroleum source potential of Cretaceous and Lower Tertiary carbonates, South Florida basin. - Gulf Coast Association of Geological Societies Transactions, 28, pp. 357-381.

Pap, I., S. Pap 1997: Rock Eval measurements in the Pannonian Basin. - Kőolaj és Földgáz, 30, pp. 289-298. 
Pavelić, D., M. Miknić, M. Šarkotić-Slat 1998: Early to Middle Miocene facies succession in lacustrine and marine environments on the southwestern margin of the Pannonian Basin System (Croatia). - Geologica Carpatica, 49, pp. 433-443.

Peters, K.E., M.R. Cassa 1994: Applied source rock geochemistry.- In: Magoon, L.B., W.G. Dow (Eds): The Petroleum System - From Source to Trap. AAPG, 60, pp. 93-120.

Reischenbacher, D., H. Rifelj, R.F. Sachsenhofer, B. Jelen, S. Ćorić, M. Gross, B. Reischenbacher 2007: Early Badenian paleoenvironment in the Lavanttal Basin (Mühldorf Formation; Austria): Evidence from geochemistry and paleontology. - Austrian Journal of Earth Science, 100, pp. 202-229.

Reuning, L., J.J.G. Reijmer, Ch. Betzler, P. Swart, T. Bauch 2005: The use of paleoceanographic proxies in carbonate periplatform settings - Opportunities and pitfalls. - Sedimentary Geology, 175, pp. 131-152.

Rögl, F., S. Spezzaferri, S. Ćorić 2002: Micropaleontology and biostratigraphy of the Karpatian-Badenian transition (Early Middle Miocene boundary) in Austria (Central Paratethys). - Courier Forschungsinstitut Senckenberg, 237, pp. 47-67.

Šarković, M., S. Stanković, S. Milosavljević, G. Karović 1992: Petroleum geology of the southeast Pannonian Basin - Results, problems, and future exploration strategy. - In: Spencer, A.M. (Ed): Generation, Accumulation and Production of Europe's Hydrocarbons, II, Special Publication of the European Association of Petroleum Geoscientists No. 2. Springer Verlag Berlin Heidelberg, pp. 200-209.

Selmeczi, I., M. Bohn-Havas, É. Szegő 2004: Prepannonian Miocene sequences of the SW edge of the Transdanubian Central Range. Litho- and biostratigraphy. - Acta Palaeontologica Romania, 4, pp. 463-466.

Sofer, Z. 1980: Preparation of carbon dioxide for stable isotope analysis of petroleum fractions. - Analytical Chemistry, 52, pp. 1389-1391.

Švábenická, L. 2002: Calcareous nannofossils of the Upper Karpatian and Lower Badenian deposits in the Carpathian Foredeep, Moravia (Czech Republic). - Geologica Carpatica, 53, pp. 197-200.

Theodoridis, S. 1984: Calcareous nannofossil biozonation of the Miocene and revision of the helicoliths and discoasters. - Utrecht Micropaleontological Bulletin, 32, pp. 1-271.

Troskot-Corbić, T., J. Velić, T. Malvić 2009: Comparison of the Middle Miocene and the Upper Miocene source rock formations in the Sava Depression (Pannonian Basin, Croatia). - Geologica Croatica, 62, pp. 123-133.

van der Zwaan, G.J., F.J. Jorissen, H.C. De Stigter 1990: The depth dependency of planktonic/benthic foraminiferal ratios: Constraints and applications. - Marine Geology, 95, pp. 1-16.

Vető, I. 1973: Szénhidrogén anyakőzet vizsgálatok (Hydrocarbon source rock studies). - HOMG Open File Report No. 4/a/2614. (in Hungarian)

Vető, I., K. Báldi, S. Ćorić, M. Hetényi 2010: Olaj anyakőzet képződés az oxigénben gazdag, mérsékelt planktoni produktivitású bádeni tengerben (Oil source rock formation in the well oxygenated, moderate planktonic productivity Badenian Sea). - In: Pál-Molnár, E. (Ed): Medencefejlődés és geológiai erőforrások (Basin Evolution and Geological Energy Resources). GEOLitera, pp. 112-113. (in Hungarian)

Wagreich, M., P. Pervesler, M. Khatun, I. Wimmer-Fry, R. Scholger 2008: Probing the underground at the Badenian type locality: Geology and sedimentology of the Baden-Soos section (Middle Miocene, Vienna Basin, Austria). - Geologica Carpathica, 59, pp. 379-394. 